NOTE

\title{
First reported outbreak of severe spirorchiidiasis in Emys orbicularis, probably resulting from a parasite spillover event
}

\author{
Raúl Iglesias ${ }^{1, *}$, José M. García-Estévez ${ }^{1}$, César Ayres ${ }^{2}$, Antonio Acuña ${ }^{3}$, \\ Adolfo Cordero-Rivera ${ }^{4}$ \\ ${ }^{1}$ Laboratorio de Parasitología, Facultad de Biología, Campus Lagoas-Marcosende, Universidad de Vigo, 36310 Vigo, Spain \\ ${ }^{2}$ AHE (Asociación Herpetológica Española), Apartado de correos 191, 28911 Leganés, Madrid, Spain \\ ${ }^{3}$ Veterinary surgeon, OAM Parque das Ciencias Vigozoo, A Madroa, Teis 36316, Vigo, Spain \\ ${ }^{4}$ Evolutionary Ecology Group, Dept. Ecology and Animal Biology, EUE Forestal, Campus Universitario A Xunqueira s/n, \\ University of Vigo, 36005 Pontevedra, Spain
}

\begin{abstract}
The importance of disease-mediated invasions and the role of parasite spillover as a substantial threat to the conservation of global biodiversity are now well known. Although competition between invasive sliders Trachemys scripta elegans and indigenous European turtles has been extensively studied, the impact of this invasive species on diseases affecting native populations is poorly known. During winter 2012-2013 an unusual event was detected in a population of Emys orbicularis (Linnaeus, 1758) inhabiting a pond system in Galicia (NW Spain). Most turtles were lethargic and some had lost mobility of limbs and tail. Necropsies were performed on 11 turtles that were found dead or dying at this site. Blood flukes belonging to the species Spirorchis elegans were found inhabiting the vascular system of 3 turtles, while numerous fluke eggs were trapped in the vascular system, brain, lung, heart, liver, kidney, spleen, and/or gastrointestinal tissues of all necropsied animals. Characteristic lesions included miliary egg granulomas, which were mostly found on serosal surfaces, particularly of the small intestine, as well as endocarditis, arteritis, and thrombosis. The most probable cause of death in the 3 turtle specimens which were also examined histologically was a necrotic enteritis with secondary bacterial infection associated with a massive egg embolism. The North American origin of $S$. elegans, the absence of prior recorded epizootics in the outbreak area, and the habitual presence of its type host, the highly invasive red-eared slider, in this area suggest a new case of parasite spillover resulting in a severe emerging disease.
\end{abstract}

KEY WORDS: Emys orbicularis $\cdot$ Blood flukes $\cdot$ Spirorchis $\cdot$ Spirorchidiiasis $\cdot$ Mortality $\cdot$ Parasite spillover · Trachemys scripta

\section{INTRODUCTION}

Besides habitat destruction, the introduction of non-indigenous species, especially those that become invasive species, is one of the most important problems for the conservation of biodiversity (Simberloff \& Rejmanek 2011), since they can impact indigenous species through predation, competition, and/or disease transmission. The transmission of dis- eases from exotic to native species, and the impact of those new diseases upon natives, is relatively wellknown in vertebrate groups such as amphibians (Fisher \& Garner 2007, Kolby et al. 2014) and fish (Uchii et al. 2013, Hein et al. 2014). Lymbery et al. (2014) defined co-introduced parasites as those transported with an alien host to a new area and coinvading parasites as those co-introduced and then transmitted to native hosts. 
In this sense, competition between the red-eared slider Trachemys scripta elegans (Wied, 1838), which is included in the 20 worst invasive species in Spain (GEIB 2006), and the autochthonous turtles Emys orbicularis (Linnaeus, 1758) and Mauremys leprosa (Schweigger, 1812) has been extensively studied (Cadi \& Joly 2003, 2004, Polo-Cavia 2009). In contrast, although the importance of disease-mediated invasions and the role of parasite spillover/spillback as a substantial threat to the conservation of global biodiversity have recently been highlighted (Smith et al. 2006, 2009, Peeler et al. 2011, McCallum 2012, Strauss et al. 2012), the impact of alien sliders on diseases affecting indigenous European turtles is poorly known.

E. orbicularis is found in East and Central Europe, the Mediterranean countries (including some islands), and North Africa (Fritz 2001, 2003). At present, this species is threatened and declining in several regions of its range, mainly due to habitat destruction. It is therefore included in the Bern Convention and protected by European Union laws. However, it is still listed as a lower risk/near threatened species in the IUCN Red List, although its status needs updating (IUCN 2013). It has been proposed that populations from northwest Spain and from the Levant should be considered 'Critically Endangered' (CR) (Keller \& Andreu 2002). Recent studies even suggest that this category, as it has recently been applied in the particular case of Galicia (NW Spain), should also be applied nationally, due to the decrease in the area occupied by the species in recent years (Ayres 2009).

Here, we report on an outbreak of severe spirorchiidiasis affecting $E$. orbicularis caused by the blood fluke Spirorchis elegans. The North American origin of this digenean species, the habitual presence of its type host T. s. elegans in the area where the outbreak was detected, and the fact that, although turtles' health has been periodically monitored in this area over the last few years, similar epizootics or spirorchiid eggs were never detected (Segade et al. 2006) suggest a probable parasite spillover the impact of which on native populations should be a cause of concern.

\section{MATERIALS AND METHODS}

In December 2012 unusual winter activity was detected in a population of Emys orbicularis inhabiting the
Centeáns ponds $\left(42^{\circ} 7^{\prime} \mathrm{N}, 8^{\circ} 38^{\prime} \mathrm{W}\right)$ at the Gándaras de Budiño e Ribeiras do Louro wetlands (Galicia, NW Spain). Most of the turtles were found on land, lethargic, and some had lost mobility of limbs and tail. The first dead turtle was detected on 27 December, floating in one of the ponds. Ten additional turtles were found dead or dying between January and May 2013.

Necropsies were performed on all turtles after natural death. They were examined macroscopically, looking for eggs and adult parasites. The organs of 3 turtles were also examined histologically by an expert pathologist who was hired by Dirección Xeral de Conservación da Natureza (Xunta de Galicia). Blood flukes were collected by flushing saline through the heart and adjacent vascular system, fixed in Bouin's solution under light coverslip pressure, stained with Semichon's acetocarmine, cleared in clove oil, and mounted in Canada balsam. Fluke eggs were recovered from macerated intestinal tissues, and faecal contents of severely infected turtles were collected, fixed in $10 \%$ formalin, and measured microscopically. Fluke and egg measurements were made according to Platt (1993). Photographs were taken using an Olympus DP11 digital camera. All drawings were prepared with the aid of a camera lucida.

In order to estimate the status of Spirorchis infection in all populations of E. orbicularis inhabiting Galician wetlands, 84 specimens were captured by net in Centeáns (outbreak area) and Orbenlle ponds (Gándaras de Budiño e Ribeiras do Louro wetland), in the Arnoia and Avia Rivers, and in Corrubedo Natural Park (Table 1). Turtles were housed individually in plastic containers, transported to the laboratory, and maintained for 24-72 h. Faeces were collected immediately after defecation, fixed in $10 \%$ formalin, and examined for Spirorchis spp. eggs using standard sedimentation techniques. To increase the sensitivity of faecal examination, 3 stool samples were analyzed from each turtle. All turtles were released back to their original population after sample collection.

Table 1. Faecal prevalence of spirorchiid eggs in all Galician populations of Emys orbicularis

\begin{tabular}{|lccc|}
\hline Population & $\begin{array}{c}\text { Turtles } \\
\text { screened (n) }\end{array}$ & $\begin{array}{c}\text { Positive for } \\
\text { eggs (n) }\end{array}$ & $\begin{array}{c}\text { Prevalence } \\
(\%)\end{array}$ \\
\hline Centeáns ponds (Gándaras de Budiño) $^{\mathrm{a}}$ & 21 & 10 & 47.6 \\
Orbenlle pond (Gándaras de Budiño) $^{\text {Arnoia River }}$ & 10 & 1 & 10 \\
Avia River & 21 & 0 & 0 \\
Corrubedo Natural Park & 22 & 2 & 9.1 \\
a Outbreak zone & 10 & 0 & 0 \\
& & & \\
\hline
\end{tabular}




\section{RESULTS}

A number of gross pathological changes were observed in all necropsied turtles but were considered non-specific findings. They included cachexia, ascites, cardiovascular lesions, enteritis, necrotic material into intestinal lumen, petechiae, and ulcerated lesions on the gastrointestinal surface.

The most significant findings, when the animals were examined microscopically, were the presence of numerous dark brown digenean eggs in the vascular system and tissues of the brain, lungs, heart, liver, kidney, spleen, and/or gastrointestinal tract (Fig. 1a,b). Characteristic lesions included miliary egg granulomas, which were observed most readily on serosal surfaces, particularly of the small intestine. Cardiovascular lesions included endocarditis, arteritis, and thrombosis. The most probable cause of death in the 3 specimens which were examined histologically by an expert veterinary pathologist was a necrotic enteritis with secondary bacterial infection resulting from a massive egg embolism (X. de Galicia unpubl. results).

Eggs were laid by blood flukes, which were found inhabiting the cardiovascular system of Emys orbicularis. Mature flukes were only recovered from 3 turtles (up to 6 digeneans host $^{-1}$ ) despite the fact that trapped eggs were detected in all necropsied turtles. Description of trematodes (Fig. 1c,d) is as follows: body slightly fusiform, $2352 \pm 282$ (SD) (18002760) $\mu \mathrm{m}$ in length, with a length/ width ratio of $4.2 \pm 0.4(3.6-4.8)$; tegument unspined; oral sucker small, 60$102 \times 42-75 \mu \mathrm{m}$; acetabulum absent; oesophagus surrounded by glandular tissue, slightly sinuous, with radial outpocketings along most of its length and a plicate organ near caecal bifurcation; anterior end-caecal bifurcation distance $350-540 \mu \mathrm{m}(16.9-20.7 \%$ of total length); caeca inflated and slightly sinuous, containing dark residues of digesting blood and terminating 100$137 \mu \mathrm{m}$ from the posterior end (3.9$5.8 \%$ of total length); median oesophageal pouch apparently absent; testes 8-10 (typically 9), preovarian, arranged in a linear series in the intercaecal area; anterior testis $60-300 \mu \mathrm{m}$ posterior to caecal bifurcation; posterior testis contiguous to seminal vesicle; cirrus sac $80-152 \mu \mathrm{m}$ long $\times 22-42 \mu \mathrm{m}$ wide, weakly muscular, running posteriad from seminal vesicle and sinistral to ovary; genital pore $255-450 \mu \mathrm{m}$ from posterior end (14.2-18.8\% of total length); opens ventrally over left caecum; ovary elongate, post-testicular, slightly multilobed, intercaecal, dextral to cirrus sac in posterior one-fourth of body; uterus short, containing a single egg; vitellaria small, irregular follicles, located lateral to caeca from posterior portion of oesophagus anteriorly, to posterior end of caeca; some in intercaecal space; vitelline reservoir pouchlike, slightly posterior to uterus; excretory bladder a
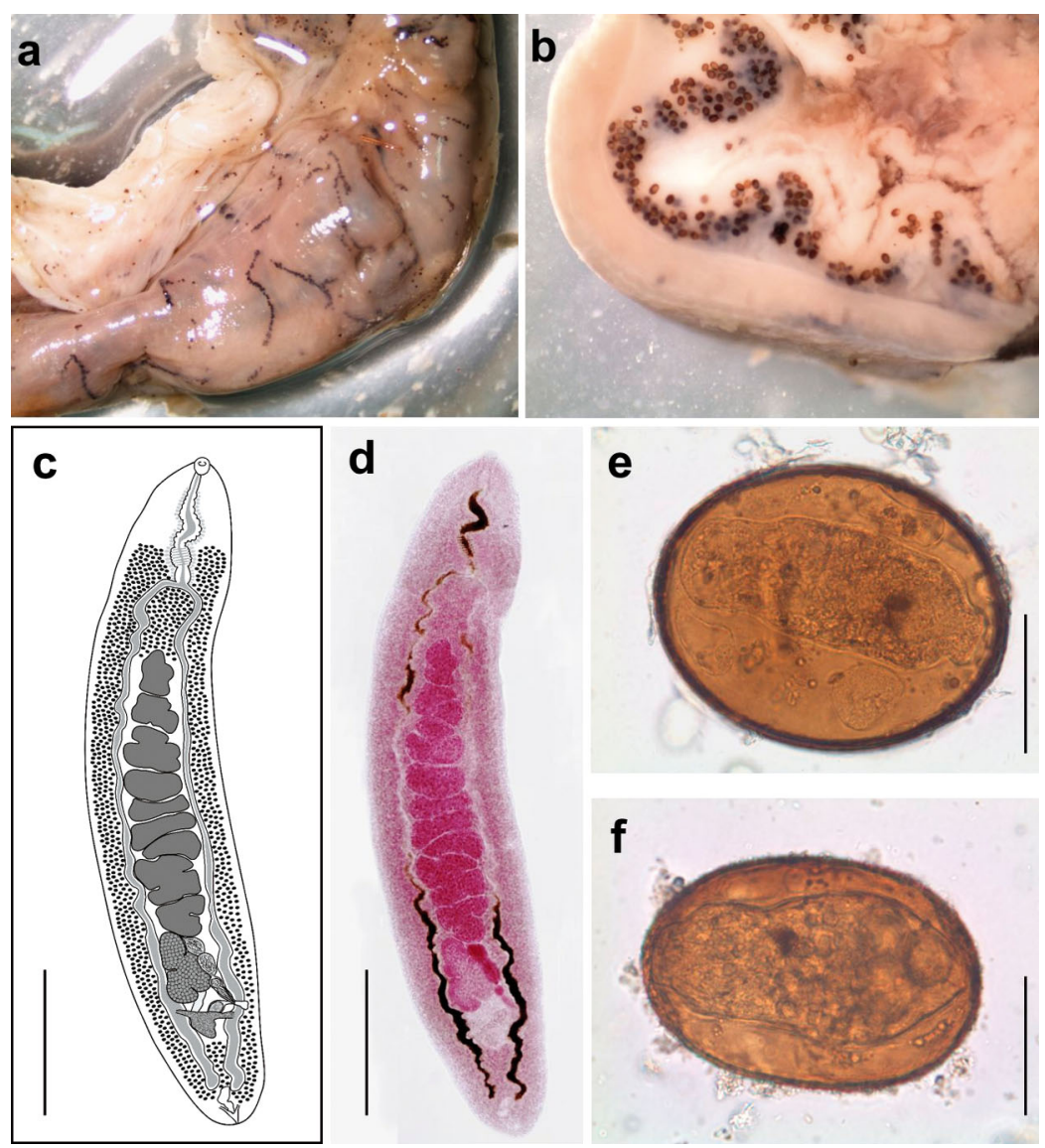

Fig. 1. $(\mathrm{a}, \mathrm{b})$ Appearance of intestinal tissues from a Spirorchis-infected Emys orbicularis turtle and (c-f) adults and mature eggs of Spirorchis species found in the vascular system of this host species. (a) External surface of the intestinal tract showing the dark lines formed by the accumulation of trematode eggs in the serosal vascular system. (b) Gross cross-section of intestine with numerous eggs concentrated in the submucosal tissues. (c) Schematic drawing and (d) photograph of mature $S$. elegans flukes showing 9 testes (dark grey in c and red in d) arranged in a linear series in the intercaecal region. Note the absence of a postovarian testis. Two mature miracidium-containing eggs obtained from (e) intestinal tissues and (f) faeces of infected turtles. Scale bars $=500 \mu \mathrm{m}(\mathrm{c}, \mathrm{d})$; $50 \mu \mathrm{m}(\mathrm{e}, \mathrm{f})$ 
short-stemmed $\mathrm{Y}$ with tubular, median accessory vesicle (Manter's organ) small, not extending into intercaecal space; operculate embryonated eggs (containing miracidium) from intestinal tissues are oval to ellipsoidal, light to dark brown in appearance, thin-shelled, and measure $127 \pm 6(122-137) \times 106 \pm$ $6(100-117) \mu \mathrm{m}$, while mature eggs from faeces are slightly smaller measuring $110 \pm 9.9(85-135) \times 82.4 \pm$ 8.2 (62.5-100) $\mu \mathrm{m}$ (Fig. 1e,f).

The coprological studies demonstrated the presence of Spirorchis spp. eggs in 10 turtles from the Centeáns ponds, 1 turtle from the Orbenlle pond, and 2 turtles from the Avia River (Table 1). As expected, the prevalence was particularly high $(47.6 \%)$ in the Centeáns population, where the outbreak of spirorchiidiasis was detected.

\section{DISCUSSION}

The family Spirorchiidae was erected (as Spirorchidae) by Stunkard (1921) for blood flukes from turtles, with Spirorchis MacCallum, 1919 as the type genus. Spirorchiids are considered highly pathogenic parasites with infections often being fatal for turtles (Goodchild \& Dennis 1967, Johnson et al. 1998, Stacy 2008). Pathogenesis is principally associated with the acute inflammatory response to migrating eggs of spirorchiids that eventually leads to granuloma formation resulting in extensive necrosis of affected tissues. Secondary infections associated with the passage of eggs through tissues, as well as constant irritation of the gastrointestinal tract causing diarrhea, starvation, dehydration, and fluid imbalance are also involved in spirorchiid pathogenicity (Goodchild \& Dennis 1967, Johnson et al. 1998, Stacy 2008).

The absence of a ventral sucker and post-ovarian testis confirms that the spirorchiids causing severe disease in Emys orbicularis clearly differ from the species Spirhapalum polesianum Ejsmont, 1927, which has been reported infecting the vascular system of this host in Poland, Russia, Ukraine, Romania, and most probably in Germany (Ejsmont 1927, Sharpilo 1960, Snyder 2004, Mihalca et al. 2007, Jennemann \& Bidmon 2009). In fact, they belong to the genus Spirorchis, in which only 8 valid species infecting the vascular system of North American freshwater turtles belonging to Chelydridae and Emydidae are recognized (Platt 1992, 1993). Although the taxonomy of Spirorchis species is still controversial and should probably be revised, the number of testes (never $<7$ ), the relatively short distance between anterior testis and caecal bifurcation, the apparent absence of a median oesophageal pouch, and the presence of a small Manter's organ not extending into the intercaecal space confirm that the specimens from E. orbicularis belong to the species Spirorchis elegans Stunkard, 1923 (Platt 1992). This species has been reported to infect the vascular system of Trachemys scripta (type host) as well as Chrysemys picta (Schneider, 1783) and Pseudemys concinna (Le Conte, 1830) in North America (Platt 1992) and most recently in the lung vasculature of $T$. s. elegans introduced in Japan (Oi et al. 2012). Our findings therefore are alarming since Spirorchis spp. have never been reported before in non-North American turtles.

Parasite transmission has previously been documented from indigenous wild populations of Mauremys leprosa and E. orbicularis to red-eared sliders in Spain (Hidalgo-Vila et al. 2009). Host switch in the opposite direction, however, has been suggested or demonstrated only in the case of American eimerians (Apicomplexa; Segade et al. 2006) and polystomes (Monogenea; Verneau et al. 2011), although the pathogenic role of these organisms is presumably low. In our case, the species $S$. elegans could have been introduced in our wetlands with this exotic turtle, since the presence of $T$. scripta in the outbreak zone has been confirmed on several occasions (Ayres et al. 2013). The results of coprological studies reveal that although no fatal cases have yet been detected outside the outbreak area (Centeáns), the parasite, or another spirorchiid with similar eggs, is also present in other populations of $E$. orbicularis inhabiting the Galician wetlands. In this sense, future molecular studies would be very helpful to confirm the precise identity of the eggs detected in the faeces of these turtles.

Studies are currently under way to investigate the dynamics of infection at the outbreak area and to identify, according to the life cycle of $S$. elegans (Goodchild \& Kirk 1960), which gastropod species (native, or most probably exotic) is acting as an intermediate host for this highly pathogenic parasite, a very important aspect which could explain why Spirorchis spp. have not been found previously in native turtles in spite of the abundance and wide distribution of invasive sliders in European wetlands (Rödder et al. 2009).

In addition, praziquantel therapy followed by faecal examinations to monitor drug efficacy (currently in progress), as well as the establishment of local eradication programs for exotic turtles, are essential for the conservation of the European pond turtle in Galician wetlands, where this species is currently at risk of extinction. 
In conclusion, our findings, together with previous investigations, support the role of invasive sliders in parasite spillover/spillback processes and competition, suggesting the necessity of increasing efforts to control the introduction and proliferation of this and other alien turtles in Europe.

Acknowledgements. We thank P. García-Diaz and O. Lorenzo-Carballa for their comments and suggestions. We are also grateful to Carles Juan-Sallés for providing us with useful information on pathology at the initial stage of the study. Part of this work was financed by Dirección Xeral de Conservación da Natureza (Xunta de Galicia).

\section{LITERATURE CITED}

Ayres C (2009) Galápago europeo-Emys orbicularis. In: Salvador A, Marco A (eds) Enciclopedia virtual de los vertebrados Españoles. Museo Nacional de Ciencias Naturales, Madrid, p 1-21. Available at: www.vertebradosibericos.org (accessed 24 May 2014)

Ayres C, Alvarez A, Ayllon E, Bertolero A and others (2013) Conservation projects for Emys orbicularis in Spain. Herpetol Notes 6:157-164

- Cadi A, Joly P (2003) Competition for basking places between the endangered European pond turtle (Emys orbicularis galloitalica) and the introduced red-eared slider (Trachemys scripta elegans). Can J Zool 81: 1392-1398

> Cadi A, Joly P (2004) Impact of the introduction of the slider turtle (Trachemys scripta elegans) on survival rates of European pond turtle (Emys orbicularis). Biodivers Conserv 13:2511-2518

Ejsmont L (1927) Spirhapalum polesianum n. g., n. sp. Trématode du sang d'Emys orbicularis L. Ann Parasitol Hum Comp 5:220-235

Fisher MC, Garner TWJ (2007) The relationship between the emergence of Batrachochytrium dendrobatidis, the international trade in amphibians and introduced amphibian species. Fungal Biol Rev 21:2-9

Fritz U (2001) Emys orbicularis (Linnaeus, 1758) — Europäische Sumpfschildkröte. In: Fritz U (ed) Handbuch der Reptilien und Amphibien Europas, Band 3/IIIA: Schildkröten I. Aula-Verlag, Wiebelsheim, p 343-515

Fritz U (2003) Die Europaische Sumpfschildkröte. Laurenti, Bielefeld

GEIB (Grupo Especialista en Invasiones Biológicas) (2006) TOP 20: las 20 especies exóticas invasoras más dañinas presentes en España. Edición patrocinada por la Fundación Territori i Paisatge de Caixa Catalunya, Serie Técnica N.2, GEIN, Léon

Goodchild CG, Dennis ES (1967) Comparative egg counts and histopathology in turtles infected with Spirorchis (Trematoda: Spirorchiidae). J Parasitol 53:38-45

Goodchild CG, Kirk DE (1960) The life cycle of Spirorchis elegans Stunkard, 1923 (Trematoda: Spirorchiidae) from the painted turtle. J Parasitol 46:219-229

Hein JL, Arnott SA, Roumillat WA, Allen DM, de Buron I (2014) Invasive swimbladder parasite Anguillicoloides crassus: infection status 15 years after discovery in wild populations of American eel Anguilla rostrata. Dis Aquat Org 107:199-209
Hidalgo-Vila J, Díaz-Paniagua C, Ribas A, Florencio M, Pérez-Santigosa N, Casanova JC (2009) Helminth communities of the exotic introduced turtle, Trachemys scripta elegans in southwestern Spain: transmission from native turtles. Res Vet Sci 86:463-465

IUCN (International Union for Conservation of Nature) (2013) The IUCN Red List of threatened species, Version 2013.1. Available at: www.iucnredlist.org (accessed 2 July 2013)

Jennemann G, Bidmon HJ (2009) Infectionen mit Blutparasiten aus der Familia der Spirorchiidae bei Emys orbicularis in Deutschland - auch eine potentialle Bedrohung für die letzten einheimischen Vorkommen der Art? Schildkröten im Fokus 6:3-18

> Johnson CA, Griffith JW, Tenorio P, Hytrek S, Lang M (1998) Fatal trematodiasis in research turtles. Lab Anim Sci 48: 340-343

Keller C, Andreu AC (2002) Emys orbicularis (Linnaeus, 1758). Galápago europeo. In: Pleguezuelos JM, Márquez R, Lizana M (eds) Atlas y Libro Rojo de los Anfibios y Reptiles de España (2a impresión). DGCN-Asociación Herpetológica Española, Madrid, p 137-140

$>$ Kolby JE, Smith KM, Berger L, Karesh WB, Preston A, Pessier AP, Skerrat LF (2014) First evidence of amphibian chytrid fungus (Batrachochytrium dendrobatidis) and ranavirus in Hong Kong amphibian trade. PLoS ONE 9: e90750

Lymbery AJ, Morine M, Kanani HG, Beatty SJ, Morgan DL (2014) Co-invaders: the effects of alien parasites on native hosts. Int J Parasitol Parasit Wildl 3:171-177

McCallum H (2012) Disease and the dynamics of extinction. Philos Trans R Soc Lond B Biol Sci 367:2828-2839

- Mihalca AD, Gherman C, Ghira I, Cozma V (2007) Helminth parasites of reptiles (Reptilia) in Romania. Parasitol Res 101:491-492

> Oi M, Araki J, Matsumoto J, Nogami S (2012) Helminth fauna of turtle species introduced in Japan, the redeared slider turtle (Trachemys scripta elegans). Res Vet Sci 93:826-830

Peeler EJ, Oidtmann BC, Midtlyng PJ, Miossec L, Gozlan RE (2011) Non-native aquatic animals introductions have driven disease emergence in Europe. Biol Invasions 13: 1291-1303

Platt T (1992) A phylogenetic and biogeographic analysis of the genera of Spirorchinae (Digenea: Spirorchidae) parasitic in freshwater turtles. J Parasitol 78:616-629

Platt T (1993) Taxonomic revision of Spirorchis MacCallum, 1919 (Digenea: Spirorchidae). J Parasitol 79:337-346

Polo-Cavia N (2009) Factores que afectan a la competencia entre el galápago leproso (Mauremys leprosa) y el introducido galápago de Florida (Trachemys scripta). PhD dissertation, Universidad Autónoma de Madrid, Madrid

Rödder D, Schmidtlein S, Veith M, Lötters S (2009) Alien invasive slider turtle in unpredicted habitat: a matter of niche shift or of predictors studied? PLoS ONE 4: e7843

Segade P, Crespo C, Ayres C, Cordero A, Arias MC, GarcíaEstévez JM, Iglesias-Blanco R (2006) Eimeria species from the European pond turtle, Emys orbicularis (Reptilia: Testudines), in Galicia (NW Spain), with description of two new species. J Parasitol 92:69-72

Sharpilo VT (1960) New records of helminths from reptiles in the U.S.S.R. Seriya B, Dopovidi Akademiyi Nauk Ukrayins'koi RSR, Kiev, p 1120-1123 (in Russian) 
Simberloff D, Rejmanek M (2011) Encyclopedia of biological invasions. University of California Press, Berkeley, CA

Smith KF, Sax DF, Lafferty KD (2006) Evidence for the role of infectious diseases in species extinction and endangerment. Conserv Biol 20:1349-1357

Smith KF, Acevedo-Whitehouse K, Pedersen AB (2009) The role of infectious diseases in biological conservation. Anim Conserv 12:1-12

Snyder SD (2004) Phylogeny and paraphyly among tretrapod blood flukes (Digenea: Schistosomatidae and Spirorchiidae). Int J Parasitol 34:1385-1392

Stacy BA (2008) Spirorchiid trematodes of sea turtles in Florida: associated disease, diversity, and life cycle studies. $\mathrm{PhD}$ dissertation, University of Florida, Gainesville, FL

Editorial responsibility: Lee Skerratt,

Townsville, Queensland, Australia
Strauss A, White A, Boots M (2012) Invading with biological weapons: the importance of disease-mediated invasions. Funct Ecol 26:1249-1261

Stunkard HW (1921) Notes on North American blood flukes. Am Mus Novit 12:1-5

Uchii K, Okuda N, Minamoto T, Kawabata Z (2013) An emerging infectious pathogen endangers an ancient lineage of common carp by acting synergistically with conspecific exotic strains. Anim Conserv 16:324-330

Verneau O, Palacios C, Platt T, Alday M and others (2011) Invasive species threat: parasite phylogenetics reveals patterns and processes of host-switching between nonnative and native captive freshwater turtles. Parasitology 138:1778-1792

Submitted: May 28, 2014; Accepted: October 6, 2014 Proofs received from author(s): January 13, 2015 